\title{
A Comparison of the Exchange of Populations in Greek and Turkish Novels
}

\author{
By Asli Emine Comu*
}

\begin{abstract}
The Exchange of Populations was of great importance for both Greece and Turkey and viewed as a key means of nation-building, especially of homogenizing ethnic diversity in the two states. Over the years historians, researchers, journalists and novelists from both sides of the Aegean have shown interest in the subject and broadened the horizon of the readers on the topic. Despite common features, there are significant differences in literary reception and interpretation of the compulsory population transfer. The views and interpretations of the authors cannot be considered independently of their backgrounds and biases. In connection with this statement, the paper will focus on four novels and their similar and contrasting approaches towards the Exchange of Populations and attempt to present a comparison between Greek and Turkish authors' perceptions of the phenomenon. The paper will also examine the impact of historical circumstances on the forced migration literature.
\end{abstract}

\section{Introduction}

The Lausanne Peace Conference opened on the 20 th of November 1922 with the participation of envoys from Great Britain, France, Italy, Greece and Turkey, after the cessation of hostilities between the Greek and Turkish forces in Asia Minor to discuss the fate of the last remnants of the once glorious Ottoman Empire. ${ }^{1}$ The victorious commander of the Turkish army in the Greco-Turkish War, İsmet İnönü, was chosen to represent the Turkish delegation, while Eleftherios Venizelos, the most prominent politician of modern Greece, was charged with leading the negotiations on their behalf.

At the conference, İnönü spoke for a country which had risen from being the underdog to victory and he actually endeavored to secure an "honorable peace" based on the National Pact that emphasized complete territorial, political, and economic independence. ${ }^{2}$ In other words, with a clean slate, he helped to shape the future of the new Turkish state and release it from the bonds that confined its predecessor, the Ottoman Empire. The large number of questions waiting to be settled in the conference were delegated to three commissions which focused respectively on territorial and military issues, minority regime, and financial and economic problems. The Greek refugee crisis which was one of the most compelling and urgent problems facing the

\footnotetext{
*Assistant Professor, Cukurova University, Turkey.

1. Erik Jan Zürcher, Turkey A Modern History (London: I.B. Tauris \& Co, 2003), 160-161.

2. Roderic Davison, Essays in Ottoman and Turkish History, 1774-1923 The Impact of the West (Texas: University of Texas Press, 1990), 211-212.
} 
conference was discussed in the Territorial and Military Commission under the chairmanship of the British representative Lord Curzon between the $1^{\text {st }}$ of December 1922 and the $27^{\text {th }}$ of January 1923, and the compulsory separation of two populations emerged as the best solution to relieve this human catastrophe. ${ }^{3}$

The Exchange of Populations Convention was signed on the $30^{\text {th }}$ of January 1923. The first article of the convention declared a forced population transfer between Turkish nationals of the Greek Orthodox religion established in Turkish territory, and of Greek nationals of the Muslim religion established in Greek territory. The people subjected to the exchange were not allowed to return to live in Turkey or Greece without the authorization of both contracting states. The migrants were to lose the nationality of the country which they were leaving and were to acquire the nationality of the country of their destination upon their arrival. Only the Greek inhabitants of İstanbul and Muslim inhabitants of Western Thrace were exempted from the scope of the population exchange. ${ }^{4}$

The Convention both had a retrospective and prospective impact by binding the population who had already left and the ones that still remained in Turkey and Greece. Over one million Greeks fled from Turkey and the estimated 800,000 Muslims in Greece had been reduced by half due to prior migrations. "In 1923, it was estimated that 189,916 Greeks in Turkey were subject to exchange and the Turkish population in Greece whose number was estimated at 355,635 was designated for removal under the terms of the Convention." 5 The Exchange of Populations affected the lives of almost 1,6 million people living in both sides of the Aegean, eventually altered the cultural, human and political geography of Macedonia, Thrace and Asia Minor, the former multinational and multireligious provinces of the Ottoman Empire and attained ethnic and social homogeneity by the efforts of the nationalist leaders of the modern age. ${ }^{6}$

The Exchange of Populations is accepted as unique but not without precedent in history. Bulgaria, Greece and the then Ottoman Empire reached consensus on population transfers between their states a decade before 1923 . The first agreement related to the population exchange was signed between Bulgaria and the Ottoman Empire in September 1913, which envisaged a

3. Aslı Emine Çomu, Turks at the Transition from Empire to Republic (İstanbul: Libra Kitap, 2016), 10.

4 The full text of the Convention can be found in Crossing the Aegean An Appraisal of the 1923 Compulsory Population Exchange Between Greece and Turkey, ed. Renée Hirschon (Oxford: Berghahn Books, 2003), 3-12.

5. Çomu, 13. As mentioned above, these recorded numbers reflect the remaining population subjected to the Exchange of Populations in both countries. The majority of them had already left their places of origins which unofficially initiated the trend of events that led to the Exchange of Populations.

6. Ibid, 14. 
population transfer within 15 kilometers of the entire common frontier. ${ }^{7} \mathrm{~A}$ Mixed Commission which was composed both of Bulgarian and Turkish delegates confirmed the status of already migrated population and oversaw the transfer of the remaining inhabitants of Bulgarian and Muslim villages in the Ottoman Empire and Bulgaria respectively. As a result, approximately 100,000 people were exchanged between the two states but the appraisal and liquidation of their properties were never carried out. ${ }^{8}$

Another exchange of populations' agreement was planned to be effectuated between Greece and the Ottoman Empire in 1914 after the displacement of almost a quarter of a million Greeks from Eastern Thrace and the Western Anatolian littoral by the Ottoman government which resented the Greek annexation of the Aegean islands along the Anatolian coast. The negotiations discontinued due to the outbreak of the First World War but a partial exchange of populations occurred since 150,000 Muslims left Greece and 250,000 Greeks quitted the Ottoman Empire. ${ }^{9}$ Finally, at the end of the Great War, a convention was signed between Bulgaria and Greece at Neuilly-surSeine providing for the reciprocal voluntary migration of the racial, religious and linguistic minorities between the two states. ${ }^{10}$ Due to its voluntary nature, not that many people applied for migration. However, after the collapse of the Greek forces in Asia Minor in 1922, the life of the Bulgarians living in Greek Macedonia became more precarious and they decided to leave Greece under the terms of the convention. ${ }^{11}$

The exchange of Greek and Turkish populations departs from its precedents by its compulsory and systematic nature. It appeared as the most practical and effective solution to end hostilities between the two contracting states and "to secure the true pacification of the Near East" at the Lausanne Peace Conference. ${ }^{12}$ In fact, both sides, Turkey and Greece, were inclined to the idea of compulsory population transfer for their own reasons. Venizelos was in support of the exchange of populations due to the massive Greek refugee influx ${ }^{13}$ and the Turkish side approached it as a way to expel of all the non-Muslim population in retaliation for "their past mistakes."14 The Great

7. Stephen P. Ladas, The Exchange of Minorities Bulgaria, Greece and Turkey (New York: Macmillan Company, 1932), 19.

8. Ibid, 19-20.

9. Charles P. Howland, “Greece and Her Refugees” Foreign Affairs, 4(1926): 616.

10. J. R. "The Exchange of Minorities and Transfers of Population in Europe since 1919: I," Bulletin of International News, 21(1944):579.

11. Ibid, 582-584.

12. Christa Meindersma, "Population Exchanges: International Law and State Practice-Part 1," International Journal of Refugee Law, 9(1997) : 340.

13. Onur Yıldırım, Diplomacy and Displacement Reconsidering the Turco-Greek Exchange of Populations, 1922-1934 (New York: Routledge, 2006), 50.

14. Ibid, 64 . 
Powers were also in favor of the population transfer; even Lord Curzon, the head of the British delegation, declined a voluntary exchange on the grounds of the undesired prolongation of the refugee settlement process. ${ }^{15}$

However, the target populations within the scope of the convention were opposed to the fact that they had to leave and were not allowed to return to their hometowns. ${ }^{16}$ A group of Turks living in Greece appealed to the Greek government for permission to stay. ${ }^{17}$ Some of the would-be refugees in Turkey converted to Islam and a considerable number of non-Muslim women married Muslims in order to avoid the population exchange. ${ }^{18} \mathrm{As}$ a matter of fact, conversion was not only attractive to Christians but also a group of Cretan Muslims informed the Greek officials about their desire for baptism. Thus they could be registered as Greeks and did not have to depart for Turkey. ${ }^{19}$

Public opinion was so aroused that the Greek and Turkish governments did not want to take the blame and held the other responsible for the human suffering. ${ }^{20}$ Finally, delegates at the conference created an air of inevitability about the compulsory nature of the population transfer as Lord Curzon stated "that the solution now being worked out should be the compulsory exchange of populations- a thoroughly bad and vicious solution, for which the world would pay a heavy penalty for a hundred years to come." ${ }^{21}$ By ignoring basic human rights, delegates gave priority to state interests and set a dangerous precedent for future ethnic conflicts. ${ }^{22}$ Therefore, people subjected to the exchange were given no right to choose and were compelled to submit to the convention, which deepened their trauma of forced migration.

The paper will concentrate on this anguish of forced displacement along with its background which varies widely from Greek to Turkish authors and its emergence as a significant theme on the national literary scene of both Greece and Turkey. The paper will aim to make a comparison on the reception of the subject in the literary community by taking into consideration of four popular novels written by Greek and Turkish authors from the 1960s through the 2010s. The comparison will focus on the expression of grief, migrants' approach to the compulsory population transfer and the primary adaptive methods that they chose to adapt to their new environments. As a preliminary

15. Meindersma, 340-341.

16. Ibid, 341.

17. Yıldırım, 79.

18. Ibid, 107.

19. Bruce Clark, Twice A Stranger How Mass Expulsion Forged Modern Greece and Turkey (London: Granta Books, 2006), 158.

20. Meindersma, 341-342.

21. Ibid, 342.

22. Renée Hirschon, "'Unmixing Peoples' in the Aegean Region" in Crossing the Aegean An Appraisal of the 1923 Compulsory Population Exchange Between Greece and Turkey, ed. by Renée Hirschon (Oxford: Berghahn Books, 2003), 10. 
to the discussion of the subject, it could be stated that the chosen Greek novels appear and are more in nature of personal accounts and memoirs of the authors whereas the Turkish novels blend historical facts with fiction and contain a long narrative full of minute details, which affected the length of the analysis of two sections.

\section{The Perception of the Exchange of Populations in Greek Novels}

The Exchange of Populations was one the most traumatic experiences in Greek history. Greece, a small country of less than six million, had to absorb a population of up to 1.3 million people deprived of even the basic necessities of life such as food, clothing and shelter. In addition, Greece had not gone through such an intensive migration flow before 1922. Even though the country had received a high number of refugees from Asia Minor and Thrace after the Balkan Wars, a certain portion of them were repatriated after the Mudros Armistice in $1918 .{ }^{23}$ Due to its magnitude, Greece had no chance to renounce this tragedy and no other choice but to face it long before Turkey did.

The first academic works on the Exchange of Populations were mainly written by Greek authors. One of them, Stephen Pericles Ladas, a Greek trademark and copyright lawyer, outlines a bare bones of the compulsory population transfer, carefully observes the diplomatic negotiations at the Lausanne Peace Conference and gives the details of the refugee settlement schemes in his book, The Exchange of Minorities Bulgaria, Greece and Turkey, which was published in $1932 .{ }^{24}$ In addition, C. G. Tenekides, a Greek lawyer, and Stelio Seferiades, a Greek refugee and later a professor at the University of Athens, wrote on the subject and criticized the compulsory nature of the Exchange of Populations respectively in 1924 and 1928.25

Not only the official handling of the population transfer but also the memories of refugees were heeded and a center was established to preserve their cultural heritage in the 1920s. The Centre for Asia Minor Studies holds a valuable oral archive based on the testimonies of 5.000 refugees from all parts of Asia Minor. ${ }^{26}$ Refugees' reaction to their situation and their state of mind including their psychological and emotional distress can also be observed in the novels, which were initially written by those who personally experienced

23. Yildırım, 88.

24. More information about the book is available in the 'Bibliography' section.

25. Stelio Séfériades, "L'echange des populations," Académie de Droit International 24 (1928):307-439; C. G. Ténekides, "Le statut des minorities et l'echange obligatoire des populations gréco-turques," Revue Générale de Droit International Public, 31(1924): 72-88.

26. For more information about the Centre for Asia Minor Studies, consult its website https://bit.ly/3dslFve (accessed 11 November 2019). 
the agony of displacement. Two of them, Benden Selam Söyle Anadolu'ya (Farewell to Anatolia) by Dido Sotiriou ${ }^{27}$ and Yitik Kentin Kırk Yilı (A Forty Year Commemoration of a Lost Town) by Kosmas Politis ${ }^{28}$ which were published in Greece in the 1960s, serve as models for this genre of popular literature.

Dido Sotiriou was a native of Asia Minor who was born in 1909 in the Aegean town of Aydin. She came from a wealthy family who migrated to İzmir after the First World War. But she had to leave for Greece as a result of the defeat of the Greek army in Asia Minor and led a middle class life in Greece due to the loss of family wealth. ${ }^{29}$ Her novel, Benden Selam Söyle Anadolu'ya, chronicles the life story of the protagonist, a Greek boy called Manolis Anxiotis, from before the Balkan Wars, through the Greek occupation of İzmir, to the Asia Minor Catastrophe in 1922.

Manolis lived in a small Greek village called Kırkıca ${ }^{30}$ near the ruins of Ephesus in Western Anatolia with his family. Kırkıca was a purely Greek village which was founded on a fertile plain endowed with abundant springs and rich flora and fauna. ${ }^{31}$ It was surrounded by Turkish villages whose inhabitants had established commercial ties and built strong relations based on mutual trust and respect with the Greeks of Kırkıca. ${ }^{32}$ Their relationships were described as firm and friendly but they lacked the feeling of brotherhood and affection. The two communities were aware of their differences. In the novel, Turkish landlords lived the life of idleness and debauchery, ${ }^{33}$ while those in the Turkish lower classes were described as ignorant and naïve. ${ }^{34} \mathrm{On}$ the other hand, Greeks were presented as shrewd, ${ }^{35}$ industrious and the best brains of Asia Minor. ${ }^{36}$

27. The original name of Dido Sotiriou's book is Matomena Chomata (Bloodstained Earth). However, it was translated into Turkish under the title Benden Selam Söyle Anadolu'ya (Farewell to Anatolia) in 1970.

28. Kosmas Politis book was first published in Greek in 1963 under the title Stou Hatzifrangou (At Hatzifrangou). It was republished in 1988 under an extended title Stou Hatzifrangou Ta Sarantachrona Mias Chamenis Politeias (At Hatzifrangou A Forty Year Commemoration of a Lost Town), which was also used in the Turkish publication in 1992.

29. Peter Mackridge,"The Myth of Asia Minor in Greek Fiction" in Crossing the Aegean An Appraisal of the 1923 Compulsory Population Exchange Between Greece and Turkey,ed. by Renée Hirschon (Oxford: Berghahn Books, 2003), 237.

30. Kırkıca is today's Şirince, a very popular town of Aegean.

31. Dido Sotiriyu, Benden Selam Söyle Anadolu'ya, trans. by Attila Tokatll, $12^{\text {th }}$ ed. (İstanbul: Alan Yayıncilık, 1996), 12-13.

32. Ibid, 17.

33. Ibid, 23.

34. Ibid, 34.

35. Ibid, 21.

36. Ibid, 55. 
Moreover, love affairs between different communities were not common and they were mostly condemned by society. In the novel, an old Greek man warned the young ones by telling an anecdote of a Greek man and a Turkish woman, who madly fell in love, got married and had a son who was stabbed to death as a result of paying the penalty of his parents. ${ }^{37}$ Manolis also had mixed feelings of pity, disgust and fear when he fell in love with a Turkish girl during the First World War, while he was living in the service of a Turkish farmer after he was drafted for forced labor and assigned to a labor battalion. ${ }^{38}$

The distant but respectful relationship of Greeks and Turks began to deteriorate after the Balkan Wars when the Young Turk government tried to incite Turks against Greeks. ${ }^{39}$ Turkish hatred intensified after the outbreak of the First World War, mainly due to the efforts of the Germans who were manipulating and guiding the Turks. ${ }^{40}$ Turks at the beginning resisted these attempts but they were eventually convinced by the promise of Greek wealth and money. ${ }^{41}$ In reprisal, Greeks formed armed bands to protect their communities from Turkish attacks. ${ }^{42}$ The Greek occupation of İzmir was the breaking point of Turkish and Greek relations. Greeks were drunk with excitement and they drew a parallel between the arrival of the Greek army and the resurrection of Jesus Christ. ${ }^{43}$ Their arrival would finally end their five century long enslavement. In the novel, the reader is constantly reminded of the Greek past of Asia Minor. Thus with the Greek occupation these territories were finally returned to their rightful owners. But the tide turned against the Greeks when the Great Powers withdrew all their support and left them on their own. It therefore follows that they could not live together with the Turks as before due to mutual hatred and all kinds of barbarism. ${ }^{44}$

Dido Sotiriou presented the Exchange of Populations as the heaviest price thus far Greeks had paid for their misdeeds. Her protagonist, Manolis, had to leave Asia Minor, the fertile land of his forefathers, with the rest of his countrymen, for the rugged and barren land of Greece. They chased after a dream which was so heavily reliant on the promises of the Great Powers who abandoned them to their fate. Anguish and remorse were the dominant feelings that were sensed at the end of the novel, which reflected the involuntary loss of their ancestral lands.

Yitik Kentin Kirk Yilı which was also published during the same period presents a personal account of loss and grief of its author, Kosmas Politis who

37. Ibid, $26-27$.

38. Ibid, 93-95.

39. Ibid, 44 .

40. Ibid, 44,55 .

41. Ibid, 61-62.

42. Ibid, 65 .

43. Ibid, 135.

44. Ibid, 166-167. 
was born in Athens in 1888. When he was two years old, his family moved to İzmir where he stayed and worked as a clerk in various banks until the collapse of the Greek army in $1922 .{ }^{45} \mathrm{He}$ was as much a refugee as Dido Sotiriou was and his novel Yitik Kentin Kirk Yil also reflects his ardent yearning for his hometown. The novel centers around the lives of Greeks living in the quarter called Hacifrangu in İzmir at the turn of the twentieth century. The author depicted his hometown, İzmir, as a beautiful and cosmopolitan city with lively streets full of cafes, shops, and vibrant fresh food markets. It was also pictured as a multinational melting pot with an incredible diversity of European, Levantine, Greek, Armenian, Jewish and Turkish cultures.

Politis did not make much room for the Turkish characters in the novel but one of them stood out, the police commissioner Hafız Efendi, who was a migrant from Thessaly and fluent in Greek. After the overthrow of the Ottoman control in that region, his father could only endure Greek rule for three years and eventually left Thessaly for Bursa. ${ }^{46}$ Intercommunal relations did not prevail in the novel but in a rare incident, Greek boys were cursed by Turks, mainly by Cretan refugees, while they were passing through the Turkish quarter. Further conflict was prevented by the warning of a Cretan who stated that the harassment of Greeks was forbidden by sultan's order. ${ }^{47}$

In contrast to Turks, a Jewish family, who migrated from Corfu and eventually settled in Hacifrangu played a central role in the novel. Since they spent all of their lives among Greeks and living within that culture, they felt themselves as foreigners in the Jewish quarter. ${ }^{48}$ Even though they were accustomed to the Greek culture and fluent in Greek, the only daughter of the family, Perla, stated that she would only marry a Jew despite of her flirting with Greek boys. They were not religious but their customs and rituals commanded them to do so. ${ }^{49}$ Towards the end of the novel, Jews were held responsible for the missing of a Greek boy and the Jewish family had to leave the quarter due to hostile and aggressive behavior of the Greeks. ${ }^{50}$

Except for a few occurrences, intercommunal relations were presented as serene but aloof. Turkish and Greek inhabitants of İzmir were similarly quite superstitious and they both made offerings to the statue of the weeping Virgin Mary for miracles. ${ }^{51}$ However, their expectations about the future were different from each other. Greeks were aware of the Greek past of Asia Minor, thus children were taught the ancient Greek names of the region by their

45. Mackridge, 238.

46. Kozmas Politis, Yitik Kentin Kırk Yılı İzmir'in Hacıfrangu Semtinden, trans. by Osman Bleda, $2^{\text {nd }}$ ed. (İstanbul: Belge Yayınları, 1994), 29.

47. Ibid, 68 .

48. Ibid, 48.

49. Ibid, 82-83.

50. Ibid, 271.

51. Ibid, 106-107. 
teachers. They were hiding weapons for the Megali Idea, the unification of all historical Greek lands, and waited for the resurrection of King Constantine. ${ }^{52}$ Although not harassed, they did not feel free under the yoke of Turkish rule. ${ }^{53}$ On the other hand, Turks resented the autonomy of Crete, which was granted after the Greco-Turkish War of $1897 . .^{54}$ Most of the Turks were aware of the fact that the course of events was not in favor of the empire but some, like police commissioner Hafız Efendi, believed that Young Turks could change the tide of destiny. ${ }^{55}$

The road to the Exchange of Populations was summarized in a brief interlude. In this section, it was stated that Turks left Asia Minor in the hands of Germans who promised to cleanse these territories of the Greek population. They were successful at inciting Turks against Greeks who were assigned to labor battalions and endured horrible conditions during the First World War. ${ }^{56}$ In the author's view, the Great Powers were to the main cause of the Asia Minor Catastrophe as they did not feel pity for the land and its inhabitants and had sent the Greek forces, foreigners, who seemed to have no palpable connection with the land. ${ }^{57}$ Turks showed respect to Greeks prior to the hatred and armed conflicts but everything changed after that because the Greeks took up arms against their homeland and were eventually labeled as traitors. ${ }^{58}$ The interlude closed with the burning of İzmir, which marked the end of the Greek presence in Asia Minor.

Both Sotiriou and Politis described the mutual relations between Greeks and Turks as respectful, trusting but also distant. They seemed to have maintained tolerance to each other. The crucial turning point in their relations was the interference of the Great Powers, who pursued their own interests. Germans lured Turks with prospects of Greek wealth and Britain and France promised Greeks the land of their forefathers. Mutual relations deteriorated to such a point that coexistence was no longer possible. Greeks were aware of their misdeeds but tried to justify their acts by emphasizing their centurieslong ties to Asia Minor. The novels were filled with regret and yearning but also reflected the heavy burden of forced migration as the incomparable price they paid for their wrongdoings. The longing for homeland was prevalent in the novels since they were written by those who personally experienced the forced separation and resettlement. The genuine feeling of loss was strong enough to evoke the sympathy and emotions of readers.
52. Ibid, 91.
53. Ibid, 191.
54. Ibid, 140.
55. Ibid, 32.
56. Ibid, 169.
57. Ibid, 170-171.
58. Ibid, 168. 


\section{The Perception of the Exchange of Populations in Turkish Novels}

The Exchange of Populations was one of the largest Turkish migration flows towards Asia Minor in the twentieth century. However, besides its compulsory nature, it was not unique; thus it did not excite some kind of uncommon attention and a spirit of extraordinary compassion. This seems to be related to the fact that the Ottoman Empire had turned into an asylum for Muslim migrants and refugees starting from the second half of the nineteenth century. Due to the Russian advance on Crimea and the Caucasus, hundreds of thousands of Muslims were forced to leave their hometowns and seek refuge in Ottoman lands. Approximately 1.5 million people, mostly Tatars, Circassians and Abhazians fled to the empire under desperate conditions. ${ }^{59}$ On the other hand, the rise of nation-states on former Ottoman territory in the Balkans generated another migration and 800,000 refugees arrived in the empire in the nineteenth century. Furthermore, 413,922 Muslims found shelter in the empire after the Balkan Wars of 1912-13. ${ }^{60}$

The Exchange of Populations could be accepted as a continuation of the former Muslim migrations, but nevertheless it received enough attention from official circles. The influx of Muslim migrants was seen "as a factor strengthening the cohesion and homogeneity of the Turkish nation." 61 The main purpose of the population exchange as stated by Şükrü Kaya, the then Minister of Internal Affairs, in 1931, was,

The primary debt of a nation, the highest duty of a government is to assure the unity of a nation within its country. The basis of the convention of population exchange implemented in Lausanne is related with this object and formed for this object. ${ }^{62}$

Therefore, the migrants subjected to the Exchange of Populations were planned to be integrated into Turkish society and they were expected to share the common identity of Turkish citizens. Their distinct characteristics were to be eliminated and blended into the whole. Most importantly, they were included into the scope of the campaign, Vatandaş Türkçe Konuş (Citizen, Speak Turkish) because a majority of them could not speak Turkish, which caused disappointment in

59. Justin McCarthy, The Ottoman Turks An Introductory History to 1923 (London: Longman, 1997), 336-337.

60. Ahmet Akgündüz, "Migration to and from Turkey, 1783-1960: Types, Numbers and Ethno- Religious Dimensions," Journal of Ethnic and Migration Studies, 24 (1998): 99.

61. Erol Ülker, "Assimilation of the Muslim Communities in the First Decade of the Turkish Republic (1923-1934)," European Journal of Turkish Studies [Online], http:/7ejts. revues.org/index822.html.

62. Ibid. 
some politicians. ${ }^{63}$ As a result, government policies succeeded in homogenizing the population and migrants' peculiarities eventually wore off.

The obscureness of migrants was also reflected in academic studies, which treated the Exchange of Populations as an ordinary migration flow until the 1990s. One of the first books which was particularly focused on the Exchange of Populations was written by Kemal Arı in 1995. In his book, Büyük Mübadele Türkiye'ye Zorunlu Göç (The Great Exchange of Populations Compulsory Migration to Turkey), he presented a detailed examination of the forced migration and its economic and political repercussions in Turkey. His book created a revival of interest in the subject and various books, theses, dissertations and, to a lesser degree, articles have been written on the subject since 1995 . Oral history studies and compilations of memoirs of the first generation of migrants also became common. Kemal Yalçın's Emanet Çeyiz (Entrusted Dowry) and İskender Özsoy's İki Vatan Yorgunları (The Exhausted of the Two Homelands) stand as the two most cited examples of this genre. Furthermore, a non-governmental organization called Lozan Mübadilleri Vakfi (The Foundation of Lausanne Treaty Emigrants) was founded by mainly second generation of migrants in 2001in order to create greater awareness among the public of the subject. For this purpose, the foundation has organized various conferences and workshops and issued many publications on the topic. ${ }^{64}$

In addition to academic studies, literary works also showed an increase during the same period. References to the Exchange of Populations were very few and mostly indirect until $1960 .{ }^{65}$ However, starting from the 1990s, quite a number of novels have been published on the subject. Some of them were written by the second and third generation of migrants as in the form of collecting family records and blending them with fiction in their writing. ${ }^{66}$ Other authors with no migrant past, showed interest in the topic due to its tragic and romantic aspects. Two recent publications, Mor Kaftanl Selanik (Thessaloniki in Purple Caftan) by Yilmaz Karakoyunlu and Bir Avuç Mazi (A

63. Çomu, 196-197. The main target of the campaign was the assimilation of nonMuslim minorities to the majority language community. However, "this movement incited other Turkish speakers to closely watch and listen to their fellow citizens to detect and condemn any use of a non-Turkish language." [Senem Aslan, " "Citizen, Speak Turkish!": A Nation in the Making," Nationalism and Ethnic Politics, 2(2007): 246.]

64. For more information about the foundation, consult its website https://bit.ly/ 2ABkLhk (accessed 18 October 2019).

65. Hercules Millas, "The Exchange of Populations in Turkish Literature: The Undertone of Texts" in Crossing the Aegean An Appraisal of the 1923 Compulsory Population Exchange Between Greece and Turkey,ed. by Renée Hirschon (Oxford: Berghahn Books, 2003), 221.

66. Kemal Arı, "Türk Roman ve Öyküsünde "Mübadele," Atatürk ve Türkiye Cumhuriyeti Tarihi Dergisi, I (2017): 23. 
Handful of Past) by Fügen Ünal Şen, which were both published in 2012, will be discussed in this section.

Yilmaz Karakoyunlu was born in a family from Diyarbakır in 1936 in İstanbul. Besides his career as a novelist, he is a politician and a former member of the Turkish Grand National Assembly. His book, Mor Kaftanl Selanik is a compilation of stories from various parts of Turkey and Greece, mainly from İzmir, Tekirdağ, Thessaloniki, Drama and Rethymno, to reflect the impact of the Exchange of Populations on both sides of the Aegean. It not only includes the psychological distress of migrants related to their forced displacement but it also reflects the official procedure behind the compulsory population transfer through the imaginary conversations between Mustafa Kemal Atatürk and his friend and head of the Turkish delegation to Lausanne, İsmet İnönü and also between Eleftherios Venizelos and his friend Aristeidis Stergiadis, the Governor-General of İzmir from 1919 to 1922.

The book covers a period longer than a year starting from the preLausanne days to the arrival of the first migrant groups to their new places of residence. All the characters from different cities were subjected to the compulsory exchange and they all reacted to their departure with an equal measure of sadness and gloom. The married couple from İzmir, Eleni and Philip, were quite reluctant to leave but they were aware that the dreadful acts of the past would not let them live peacefully as before. ${ }^{67}$ Even though the Great Fire of İzmir was mentioned briefly in the book, 68 it seems that this catastrophe did not have a direct effect on their house, which they entrusted to their Turkish neighbors who came to bid farewell in tears. ${ }^{69}$

In Drama, while Hasan Hodja was waiting for his departure, he had a long conversation with his childhood friend, Sokratis, who told him that everything had turned upside down for Turks and Greeks when Thessaloniki was captured by Greece in 1912. A state of fear had grown between them, which was used as a trigger for ethnic conflict. ${ }^{70}$ Sokratis was also deeply touched by the leaving of his friend and said that it deeply hurt him to expel those who also belonged to that land. ${ }^{71}$ In Tekirdağ, the Exchange of Populations also came as a shock and despair for Greeks who would be deported to Greece under the terms of the Convention. Barba and Eva, the married owners of a tavern, refused to leave their homeland and stated that neither Athens nor Ankara cared about the migrants. ${ }^{72}$ Markos, an old and wealthy Greek whose family migrated to Tekirdağ almost a century ago

67. Yılmaz Karakoyunlu, Mor Kaftanlı Selanik Bir Mübadele Romanı (İstanbul: Doğan Kitap, 2012), 119-120.

68. Ibid, 19.

69. Ibid, 123-124.

70. Ibid, 60 .

71. Ibid, 143.

72. Ibid, 72 . 
reacted more fiercely to the compulsory population transfer and chose to hang himself instead of leaving his home. ${ }^{73}$ Barba and Eva were luckier than Markos because their Turkish friend, Captain İhsan, registered them as migrants from Alexandroupolis-which in reality was not included in the scope of the Exchange of Populations- and they managed to stay in Turkey after taking their new Turkish names, Bahri and Havva. ${ }^{74}$

In Rethymno, Muslims reacted violently to their departure ${ }^{75}$ and one of the main Turkish characters of the novel, Şerife, stayed in Rethymno, her homeland, after her marriage to Vasili, her childhood Greek friend from the neighborhood. ${ }^{76}$ This was not the only example of the interethnic marriages. Halil, who was among the Turks that left Drama, married his beloved Sofia, who secretly followed the Turkish company along their journey to Turkey. ${ }^{77}$ In another story, Şevket Bey, who was sent to exile in Thessaloniki by Sultan Abdülhamit II, believed that if the sultan had remained as the ruler of the country, they would not have been forced to leave. ${ }^{78}$ Despite his rather short stay in Thessaloniki, it is obvious that he had developed strong bonds with the city. At the end of the novel, some of the main characters, such as Hasan Hodja, Şevket Bey, Barba and Eva came together in Tekirdağ, at the Şarköy Migrant Distribution Center. ${ }^{79}$ On the other hand, Eleni was resettled in Şerife's quarter in Rethymno. She arrived at Crete without her husband, Philip, who could not endure the hard voyage and the agony of being forced to leave his homeland. 80

The emergence of the Exchange of Populations was told through the conversations of the statesmen who were held responsible for the forced displacement. The novel also made references to the homelands of both Atatürk and Venizelos. Atatürk was born in Thessaloniki and his mother and sister suffered the hardship of the migration. ${ }^{81}$ Conversely, Venizelos was raised in Chania and had many Turkish friends when he was a child. ${ }^{82}$ Even though the author accepted the responsibility of both Turks and Greeks in the Exchange of Populations, he was inclined to give a greater share of the blame to the Greek side. In the novel, İsmet Pasha was strictly against the idea of forced displacement and stated that Venizelos' plan was about accepting all

73. Ibid, 239.
74. Ibid, 367.
75. Ibid, 267.
76. Ibid, 413 .
77. Ibid, 366.
78. Ibid, 31.
79. Ibid, 378.
80. Ibid, $197,263$.
81. Ibid, 21.
82. Ibid, 33.


the artisans and merchants of the Ottoman Empire into his borders. ${ }^{83}$ Atatürk's real intention was not clearly revealed but he was more inclined to the idea of forced migration since he ordered İsmet Pasha to finalize the Exchange of Populations Convention at Lausanne without delay. ${ }^{84}$ Greeks were presented as the ones who were paying the price for their greed and evil ways. Aristeidis Stergiadis told Venizelos that they were not satisfied with their acquisitions after the Balkan Wars and they ambitiously demanded more. The British forces were weary and the British government rather sent Greeks to Asia Minor by manipulating their greed and ambition. They were successful; but Greeks had to endure the shame of the Asia Minor Catastrophe. ${ }^{85}$ Venizelos also accepted the guilt of their actions during the Greco-Turkish War of 1919-1922, which was presented as the main cause of the compulsory population transfer by the author. ${ }^{86}$

In the novel, the leaving of homelands was presented as a heavy burden which became difficult to carry especially for the migrants who ended their lives or died of the stress caused by being forced to depart their homes. Nevertheless, most of the migrants felt motivated and hopeful about the future. They realized the bitter fact that no turning back was possible for them, so they were ready and able to say farewell to their past and embrace their new lives. Their loss made their hearts heave in constant agony but they gradually learned to deal with it. The novel ends with positive and encouraging remarks about the future potential of migrants on both sides of the Aegean.

In contrast to Karakoyunlu, Fügen Ünal Şen, a journalist and a third generation migrant, preferred to focus on the story of just one Turkish migrant family and pointed out the financial and emotional damage they suffered during their forced displacement in her book, Bir Avuç Mazi. Fethi Bey was the head of the family who was born and raised in Elassona (Alasonya), Greece. He married Cevriye and they had two daughters, Şehbal and İkbal the latter of whom recently married Sami, the son of a wealthy cloth merchant from Thessaloniki. Two storylines alternate in the text one of which centers on the last days of the family in Elassona in May 1924, the other is about their journey from their arrival port in Turkey, Mersin, to their new home in the Cilician town of Dörtyol.

The Turkish population living in Elassona had firm bounds with their homeland but during their last days in the town a climate of fear was prevalent among them. Especially after the Balkan Wars, Turks suffered from the pillage, murder and incendiary acts of Greeks, from which Fethi Bey and

83. Ibid, 29,44 .

84. Ibid, 75 .

85. Ibid, 101.

86. Ibid, 182-183. 
his family were saved with the help of his close friend Niko. ${ }^{87}$ But still they felt the pain of leaving their home in their hearts. They were also struck with a startling sense of unfamiliarity. They no longer belonged to the place they would leave, nor did they belong to Turkey. For İkbal, Turkey was a strange land; thus nobody could force them to settle there. ${ }^{88}$ They bemoaned the fact that no one had asked them whether they wanted to stay. If they did, they would probably stay despite the constant fear, uncertainty and turmoil. ${ }^{89}$ However, Fethi Bey saw the Exchange of Populations as the invitation of Mustafa Kemal; therefore they had to go because Mustafa Kemal had requested them to do so. ${ }^{90}$

Before their departure, a Greek woman with her baby was settled in their home in Elassona. ${ }^{91}$ She was subjected to the Exchange of Populations just as they were. Her name was Mitra and she was from a Thracian village called Kalikratya in close vicinity to İstanbul..$^{92}$ Mitra could not speak Greek, which created doubt about her Greekness among Greek officials. On the other hand, the majority of the Turkish population living in Elassona could only speak Greek, which caused them to be labeled as Greek descendants in Turkey. ${ }^{93}$ The author described both the Greek and Turkish migrants in the same way: "they were so exhausted, so lonely and so foreign." ${ }^{94}$ In this way, a connection was forged between the Greek and Turkish migrants who were united by the same fate and bound together on a journey to unknown places. But on the other hand, their foreignness was evident in Turkey. Besides their lack of Turkish fluency, there were notable differences among them especially between native and migrant Turkish women. Whereas the migrant women were not hiding from men, the natives were confined to indoors. ${ }^{95}$

In the novel, the family realized that they had no choice but to leave. Thus, they convinced themselves that they had better forget their hometown as soon as possible because the wound inflicted upon their soul would kill them slowly. ${ }^{96}$ On the night before their departure, Cevriye took a handful of soil from her garden in Elassona, wrapped it in a cloth and carried it in her bosom through her journey to Turkey. She squeezed it every time she needed

87. Fügen Şen Ünal, Bir Avuç Mazi Bir Mübadele Romanı (İstanbul: Everest Yayınları, 2012), 61 .

88. Ibid, 16 .

89. Ibid, 17, 41.

90. Ibid, 17.

91. Ibid, 21.

92. Ibid, 70 .

93. Ibid, 52.

94. Ibid, 19, 24.

95. Ibid, 125.

96. Ibid, 98-99. 
strength. ${ }^{97}$ When they reached their new home in Dörtyol, she found a green sprout in the soil, which she mixed with the earth of her new garden. This fragile sprout was a souvenir from her former home, which helped her to embrace her new life. ${ }^{98}$ Therefore, even though they were devastated about leaving their former homes behind, they were optimistic about their new life and had a sense of hope for the future.

Fügen Ünal Şen's novel bears certain similarities with Mor Kaftanlı Selanik. The pain of separation from home was also so intensely felt that people chose to take their own life rather than having to face the sorrow of leaving. In Bir Avuç Mazi, Sami's father, Tevfik Bey, shot himself due to the suffering caused by the compulsory population exchange. ${ }^{99}$ Additionally, conversion to Islam was also acknowledged as an effort to be exempted from the forced population transfer. In the novel, Mitra's brother, Yannis, took the Turkish name Ahmet and expected to be resettled in his village, Kalikratya, in the disguise of a complete stranger. ${ }^{100}$ Amicable interethnic relations were also mentioned through the firm friendship of Fethi Bey and Niko based on years of close personal association. Even inter-communal marriages between Turks and Greeks were existent in the novel. Cevriye's sister Cemile eloped with Gregori and eventually had a son called Aleko. ${ }^{101}$ Gregori left his wife Cemile dying after being shot while she was warning Turkish villages against the attacks of Greek armed bands in 1912. ${ }^{102}$ Therefore, even though strong interethnic ties in the form of close friendships existed, the fragile and volatile nature of these relations was implied to be vulnerable to prejudice and political emotion. Greeks were also held responsible for the shift in the reciprocal relations into a more negative direction.

However, most importantly, both Karakoyunlu and Ünal Şen depicted a future full of hope for their characters. Even though migrants grieved the loss of their hometowns, they adjusted themselves relatively easily to the change and quickly adapted to their new lives. In these novels hope was a more dominant feeling than despair, longing and regret. Since these novels were written long after the implementation of the Exchange of Populations, authors had a chance to examine the integration process of Turkish migrants into Turkish society. On the other hand, both of the authors did not personally experience the forced population transfer, so their narrative fell short of reflecting the anguish of experience. Despite their initial reactions including anger, disapproval and disappointment at forced displacement, the Exchange

\footnotetext{
97. Ibid, 187.

98.. Ibid, 254-255.

99. Ibid, 220.

100. Ibid, 194.

101. Ibid, 198.

102. Ibid, 200.
} 
of Populations gradually appeared as a reasonable and acceptable solution for the migrant community.

\section{Conclusion}

The Exchange of Populations was one of the many tragic episodes in Turkish and Greek history that affected the lives of almost 1,6 million people who endured the pain, hardship and fear of forced migration. It was also a strong subject with dramatic potential that fostered a considerable growth of interest and popularity in literary circles. Its popularity is still on the rise after new publications of many existing books, some of which have kept their best seller position such as Benden Selam Soyle Anadolu'ya. The subject is particularly attractive to those primarily interested in tracing their family history and others who want to learn more about the nation building process in both countries.

The Exchange of Populations occurred after the disastrous defeat of the Greek Army in Asia Minor which is known as the Asia Minor Catastrophe. But, on the other hand, it materialized after the Turkish War of Independence resulted in a clear Turkish victory over the Greek forces. Therefore, the approaches to the forced migration differed in the two countries due to different perceptions of shared historical events. The Greek side saw it as the heavy burden of their failures and mistakes and they recounted their wrongdoings as well as suffering in the form of a personal testimony. Their narratives only focused on their former lives in Asia Minor and comprised no information about their adaptation in Greece. However, the Turkish side approached the subject as a necessary preliminary stage in the formation of the new Turkish republic. Turkish authors were aware of the official procedure by making research on the subject and referring to the memoirs of the first generation of migrants. They fused fiction with reality and mentioned interethnic marriages and Christian and Muslim conversion efforts as methods of avoiding forced deportation. These were presented as rare exceptions in order to add another dose of tragedy to the subject. Finally they reached the conclusion that despite their initial misery, migrants were content with their lives in Turkey and remained hopeful about their future by focusing on the present and not dwelling on the past.

In the Greek novels, refugees mourned for the loss of the land of their forefathers. They genuinely regretted throwing themselves into a venture with the support of the Great Powers and becoming susceptible to every kind of evil, which led to their final separation from the almost sacred land of Asia Minor. In addition, their belonging to this land defined their distinct identity and complicated their integration into Greek society. On the other hand, Turkish migrants had a historic bond with the land but this bond was only 
consolidated with the existence of Turkish rule. The former migrations of their kinsmen from the Balkans could be accepted as a proof for this statement that they belonged to these territories for as long as the Turks were the rulers. Therefore, migrating to Turkey seemed as a logical solution for the majority of them which eased the pain of leaving their homes behind. This thought also precipitated their integration process in Turkey.

On the subject of the interethnic relations, the Greek novels approach was quite different to the Turkish ones. Greco-Turkish relations were depicted as smooth but distant by Greek authors who created an air of sufferance and implied that Greeks were groaning under the yoke of the Turkish rule. They had chosen to tolerate Turks until the day of their salvation. However, from the Turkish standpoint, interethnic relations were quite peaceful and amicable until the annexation of a large piece of Ottoman territory in the Balkans by Greece in 1912. The Balkan Wars actually marked a huge turning point in the relations between two communities when Greeks became more aggressive and violent and made the lives of Turks unbearable. In a way, Turkish authors were also pointing at Greeks as responsible for ending the possibility of their coexistence.

As a final remark, the Exchange of Populations was accepted as the best solution to the problem of Greco-Turkish conflict through homogenizing territories of both nations with the approval of the Great Powers. As mentioned before, state interests were given priority over individual human rights at the Lausanne Peace Conference and people were given no chance but to leave and to obey the convention. The novels are filling in the sparse discourse on issues related to the misery and distress of migrants especially in Turkey where they remained silent for years. These literary works also played a major role in creating a distinct identity for these migrants by identifying them with Greek ones who also endured the same journey of forced migration. Despite remaining in the background for the most part, Turkish migrants were given a separate status, which distinguished them from the rest of the Muslim and Turkish migrants in Turkey. ${ }^{103}$

103. In Turkey, people who had migrated to the country from the Balkans or the Caucasus are generally known as muhacir. However, the second and third generation of those who were subjected to the Exchange of Populations, prefer to call themselves as mübadil, in order to underline their difference. 


\section{Bibliography}

Akgündüz, Ahmet. "Migration to and from Turkey, 1783-1960: Types, Numbers and Ethno- Religious Dimensions." Journal of Ethnic and Migration Studies, 24 (1998): 97-120. http://dx.doi.org/10.1080/1369183X.1998.9976620.

Arl, Kemal. “Türk Roman ve Öyküsünde "Mübadele." Atatürk ve Türkiye Cumhuriyeti Tarihi Dergisi, I(2017): 5-28.

Aslan, Senem. "'Citizen, Speak Turkish!': A Nation in the Making." Nationalism and Ethnic Politics, 2(2007): 245-272. http://dx.doi.org/10.1080/1353711070 1293500.

Clark, Bruce. Twice A Stranger How Mass Expulsion Forged Modern Greece and Turkey. London: Granta Books, 2006.

Çomu, Aslı Emine. Turks at the Transition from Empire to Republic. İstanbul: Libra Kitap, 2016.

Davison, Roderic H. Essays in Ottoman and Turkish History, 1774-1923 The Impact of the West. Texas: University of Texas Press, 1990.

Hirschon, Renée. “Unmixing Peoples' in the Aegean Region." In Crossing the Aegean An Appraisal of the 1923 Compulsory Population Exchange Between Greece and Turkey, edited by Renée Hirschon. Oxford: Berghahn Books, 2003.

Howland, Charles P. “Greece and Her Refugees.” Foreign Affairs, 4 (1926): 613623.

J. R. "The Exchange of Minorities and Transfers of Population in Europe since 1919: I." Bulletin of International News 21(1944): 579-588.

Karakoyunlu, Yılmaz. Mor Kaftanlı Selanik Bir Mübadele Romanı. İstanbul: Doğan Kitap, 2012.

Ladas, Stephen P. The Exchange of Minorities Bulgaria, Greece and Turkey. New York: Macmillan Company, 1932.

Mackridge, Peter. "The Myth of Asia Minor in Greek Fiction. "In Crossing the Aegean An Appraisal of the 1923 Compulsory Population Exchange Between Greece and Turkey, edited by Renée Hirschon. Oxford: Berghahn Books, 2003.

McCarthy, Justin. The Ottoman Turks An Introductory History to 1923. New York: Longman, 1997.

Meindersma, Christa. "Population Exchange: International Law and State Practice Part 1." International Journal of Refugee Law, 9(1997): 335-364. https://doi.org/10.1093/ijrl/9.3.335.

Millas, Hercules. "The Exchange of Populations in Turkish Literature: The Undertone of Texts." In Crossing the Aegean An Appraisal of the 1923 Compulsory Population Exchange Between Greece and Turkey, edited by Renée Hirschon. Oxford: Berghahn Books, 2003, 221-234.

Politis, Kozmas. Yitik Kentin Kırk Yil Izmir'in Hacıfrangu Semtinden. Translated by Osman Bleda. 2nd ed. İstanbul: Belge Yayınları, 1994.

Sotiriyu, Dido. Benden Selam Söyle Anadolu'ya. Translated by Attila Tokatlı. $12^{\text {th }}$ ed. İstanbul: Alan Yayıncilık, 1996. 
Şen Ünal, Fügen. Bir Avuç Mazi Bir Mübadele Romanı. İstanbul: Everest Yayınları, 2012.

Ülker,Erol. "Assimilation of the Muslim Communities in the First Decade of the Turkish Republic (1923-1934)." European Journal of Turkish Studies [Online]. http:/7ejts.revues.org/index822.html. Accessed 11 November 2019.

Yıldırım, Onur. Diplomacy and Displacement Reconsidering the Turco-Greek Exchange of Populations, 1922-1934. New York: Routledge, 2006.

Zürcher, Erik Jan. Turkey A Modern History. London: I.B. Tauris \& Co, 2003. 